\title{
Análise das reflexões de licenciandos em química em situações de ensino
}

\section{RESUMO}

Viviane Arrigo

viviane arrigo@hotmail.com 0000-0002-0683-8387

Universidade Estadual de Londrina, Brasil.

Álvaro Lorencini Júnior lorencinijunior@yahoo.com.br 0000-0001-9365-2312 Universidade Estadual de Londrina, Brasil.

Fabiele Cristiane Dias Broietti fabieledias@uel.br 0000-0002-0638-3036

Universidade Estadual de Londrina, Brasil.

\begin{abstract}
O objetivo desta pesquisa foi identificar e analisar as reflexões de estudantes de um curso de Licenciatura em Química, bem como as implicações destas reflexões para o desenvolvimento do processo de aprender a ensinar. A coleta dos dados ocorreu por meio da Autoscopia Bifásica integrada ao microensino, procedimento que possibilitou a filmagem dos microensinos na fase interativa e, por meio de uma entrevista, a identificação das situações-problema decorrentes das práticas de cada licenciando na fase pós-ativa. Identificamos que, embora os licenciandos se deparassem com situaçõesproblema no decorrer da sua atividade docente, uma delas sempre era a responsável por desencadear as demais. Assim, buscamos investigar momentos em que eles refletiam acerca de tal situação com vistas à transformação da sua prática. Com isso, foi possível identificar os momentos da prática reflexiva dos estudantes e constatar que estes não ocorreram de forma sequencial, mas sim caracterizados por avanços e retrocessos, o que nos permitiu elaborar um modelo em espiral que ilustra os movimentos reflexivos em uma situação de prática de ensino.
\end{abstract}

PALAVRAS-CHAVE: Prática de ensino. Formação inicial reflexiva. Química. Autoscopia. 


\section{INTRODUÇÃO}

As discussões tecidas ao longo deste artigo são fruto de uma dissertação de mestrado que apresentava como principal foco de pesquisa o desenvolvimento de uma prática docente reflexiva na formação inicial de professores de Química. A leitura de referenciais a respeito desta temática (ZUCCO; PESSINI e ANDRADE, 1999; GAUCHE et al., 2008; SILVA e SCHNETZLER, 2008, 2011; SILVA e OLIVEIRA, 2009; MALDANER, 2013; BROIETTI e STANZANI, 2016) nos levou a buscar uma resposta ou pelo menos tecer algumas considerações para a seguinte questão: $D e$ que forma as reflexões dos estudantes de um curso de Licenciatura em Química podem interferir no desenvolvimento do processo de aprender a ensinar?

De acordo com Nóvoa (1992) a formação docente deve estar pautada em uma perspectiva crítico-reflexiva que forneça aos professores meios para o desenvolvimento de um pensamento autônomo, o que implica em um investimento pessoal, um trabalho livre e criativo a respeito de projetos próprios, visando a construção de uma identidade profissional. $O$ autor ressalta que

[...] é preciso reconhecer as deficiências científicas e a pobreza conceptual dos programas actuais de formação de professores. E situar a nossa reflexão para além das clivagens tradicionais (componente científica versus componente pedagógica, disciplinas teóricas versus disciplinas metodológicas, etc.), sugerindo novas maneiras de pensar a problemática da formação de professores (NÓVOA, 1992, p. 23).

Consideramos que mediante a reflexão sobre situações problemáticas de ensino, é possível superar as crenças primeiras sobre o "ser professor", formadas na relação professor/aluno/futuro professor, o que permite pensar e elaborar estratégias de formação a serem executadas, avaliadas e eventualmente modificadas na tentativa de formar um profissional em constante atualização, capaz de interagir positivamente com seus alunos, problematizar as suas vivências e (re)construir seu modo de pensar nos processos de ensino e de aprendizagem.

Nesta perspectiva, neste artigo, objetivamos identificar e analisar o conteúdo das reflexões de estudantes de um curso de Licenciatura em Química, bem como as implicações destas reflexões para a construção do processo de aprender a ensinar.

\section{A FORMAÇÃO INICIAL DE PROFESSORES - AS LICENCIATURAS}

De acordo com a Sinopse Estatística da Educação Superior, no Brasil, o número de Instituições de Ensino Superior (IES) (pública e privada) que ofertam cursos de graduação presenciais e à distância totalizam 2.407 IES. O total ofertado nas categorias Bacharelado, Licenciatura, Tecnólogo e não aplicável corresponde a 34.366 cursos. Destes, 7.356 referem-se a cursos de Licenciatura, ou seja, $21,4 \%$ do total. No entanto, um dado preocupante está relacionado a baixa procura por esses cursos, em especial os das áreas específicas de Química e Física. Das 8.048.701 matrículas efetivadas no ano de 2016, apenas 1.520.494 foram destinadas a cursos de Licenciatura e destas, 36.112 e 25.127 , foram designadas aos cursos de Licenciatura em Química e Física, respectivamente (INEP, 2016). 
Quando se fala em formação de professores, alguns autores (Gatti, 2014; Tardif, 2010) atentam para a dissonância entre o que está apresentado nos projetos políticos pedagógicos dos cursos e o conjunto de disciplinas oferecidas e suas ementas, ou seja, as ideias não se concretizam na formação realmente oferecida, bem como teorias e práticas não se mostram integradas. Gatti (2014) destaca que:

O esquema de formação híbrido que se consolidou historicamente no país, desde as origens das licenciaturas no início do século passado, postas como adendo dos bacharelados, mostra-se quase impermeável à construção de concepções específicas para a formação de professores tendo a educação e seus aspectos fundamentais como eixo curricular básico. A questão importante, no entanto, é que se oferece nesses cursos apenas um verniz superficial de formação pedagógica e de seus fundamentos que não pode ser considerado como realmente uma formação de profissionais para atuar em escolas na contemporaneidade (GATTI, 2014, p. 39).

Neste viés, Tardif (2010) se refere à formação para o magistério como algo que ocorre em uma redoma de vidro, sem conexão com a ação profissional e dominada pelos conhecimentos disciplinares, os quais devem ser aplicados na prática durante os estágios ou durante outras atividades práticas. Tal situação também é discutida por Gatti (2010) em um levantamento realizado a partir das características e problemas presentes na formação de professores no Brasil. É perceptível que os avanços ainda não foram significativos no que diz respeito às condições dos cursos de licenciatura, o que revela a necessidade de uma reestruturação dos referidos cursos.

Silva e Schnetzler (2008) argumentam que repensar os currículos das licenciaturas, em específico do curso de Química, implica, entre outras alterações, em mudanças nas concepções a respeito das disciplinas de Prática de Ensino e Estágio Supervisionado. As autoras destacam a necessidade da elaboração de novos currículos para os cursos de licenciatura pautados na racionalidade da prática, de modo que estes concebam o futuro professor não como um mero técnico que deve aplicar métodos ou regras para ensinar, mas, como um profissional que precisa estar atento às necessidades dos estudantes e da escola, que faça uso de diferentes abordagens e/ou metodologias de ensino e que reflita sobre a sua prática.

Repensar a formação inicial de professores de Química a partir da análise de como as práticas de ensino vem sendo desenvolvidas ao longo do curso tem se revelado como uma demanda de suma importância. Busca-se que a formação dos profissionais supere os moldes de um currículo normativo que segue uma ordem pré-definida, apresentando primeiramente a ciência, seguida de suas aplicações e, por fim, um estágio que supõe a aplicação pelos estudantes dos conhecimentos técnico-profissionais (CARVALHO e GIL-PÉREZ, 2003).

Nesse sentido, Broietti e Stanzani (2016) reconhecem que diante dos desafios impostos pela realidade da educação brasileira, faz-se necessário que a formação desenvolvida nos cursos de licenciatura ocorra a partir da integração de distintos conhecimentos, mediante a articulação teoria e prática, de modo a preparar os futuros professores com qualidade científica e princípios didáticos para o exercício da docência. Logo, vale destacar que atualmente os currículos dos cursos de licenciatura estão sendo reformulados à luz das solicitações presentes no parecer CNE/CP no 2/2015, que evidencia a necessidade de garantir 
durante o processo de formação do futuro professor, "efetiva e concomitante relação entre teoria e prática, ambas fornecendo elementos básicos para o desenvolvimento dos conhecimentos e habilidades necessários à docência" (Brasil, 2015, p. 30-31).

Assim sendo, destacamos que a construção do perfil docente nos cursos de licenciatura realiza-se por caminhos distintos, a partir das interações do futuro profissional com a instituição de ensino superior à qual está vinculado, com as instituições escolares, com outros profissionais e com o próprio exercício docente e, sobretudo, com as oportunidades de estudo e reflexão sobre esse mesmo quadro de referências que Ihe foi possível vivenciar desde o início de sua trajetória em direção à profissão.

\section{A EPISTEMOLOGIA DA REFLEXÃO NA FORMAÇÃO INICIAL DO PROFESSOR}

O conceito de professor reflexivo emergiu inicialmente nos EUA ao final do século XX como reação à concepção tecnocrática de professor (Alarcão, 1996). A partir daí, termos como "pensamento reflexivo" (Dewey, 1979), "profissional prático reflexivo" (Schön, 1992, 2000) e "ensino reflexivo" (Zeichner, 1993) vêm sendo apresentados e discutidos em estudos referentes à reflexão sobre a prática, os quais servem como apoio para outros autores que também defendem a ideia de prática reflexiva como uma possibilidade de os professores interrogarem as suas práticas de ensino (LORENCINI JR., 2000, 2009; ALARCÃO, 1996, 2003; PIMENTA, 2006; ROSA-SILVA, 2008).

Alarcão (2003, p. 41) afirma que "a noção de professor reflexivo se baseia na consciência da capacidade de pensamento e reflexão que caracteriza o ser humano como criativo e não como mero reprodutor de ideias e práticas que lhe são exteriores". Os estudos de Schön $(1992,2000)$ apontam que o conceito de professor reflexivo emergiu da necessidade de focar a formação profissional em uma epistemologia oposta à racionalidade técnica. Para isso, o autor defende as potencialidades da perspectiva de formação do professor reflexivo, uma formação docente baseada em uma epistemologia da prática, a qual se embasa nos conceitos de conhecimento-na-ação e reflexão-na-ação. Tal perspectiva exerce forte influência na construção da identidade profissional dos professores, o que pode levá-los à permanente descoberta de formas de desempenho de qualidade por meio de investigação e reflexão da sua própria prática.

Nesse sentido, valorizamos a prática na formação inicial dos professores, porém, uma prática reflexiva, a qual deve possibilitar a realização de processos reflexivos que levem o professor a fazer descrições do seu conhecer-na-ação, como nos fala Schön (2000). Destacamos, nesse contexto, a importância dos estágios realizados durante a licenciatura e o contato com o ambiente escolar, o que possibilita ao futuro professor, por meio da pesquisa e investigação de sua prática educativa, o desenvolvimento da capacidade de refletir mediante as mais diversas situações.

$\mathrm{Na}$ tentativa de reconhecer os elementos surpresa que emergem das diversas situações de ensino, analisá-los e solucioná-los, Schön (1992, 2000), em seus estudos, defende três processos reflexivos que podem auxiliar o professor em sua atividade docente: a reflexão-na-ação, a reflexão sobre a ação e $a$ reflexão sobre a reflexão-na-ação. 
Schön (2000) explica que a partir do surgimento de um elemento surpresa, ou seja, algo que não está de acordo com as nossas expectativas e que o nosso ato espontâneo de conhecer-na-ação não nos permite solucionar, podemos refletir sobre a ação ou na ação. A reflexão-na-ação ocorre quando o professor pensa sobre algo que the chama a atenção durante a aula; guiando-se pela intervenção que fará na situação para (re)significar o que está fazendo, enquanto ainda o faz (SCHÖN, 1992, 2000). Por isso, Schön (2000) denomina de presenteda-ação um período de tempo variável com o contexto, durante o qual ainda se pode interferir na situação em desenvolvimento.

Alarcão (2003, p. 50), baseada nas ideias schonianas também argumenta que "a reflexão-na-ação acompanha a ação em curso e pressupõe uma conversa com ela. Refletimos no decurso da própria ação, sem a interrompermos". Portanto, "nosso parar para pensar serve para dar nova forma ao que estamos fazendo, enquanto ainda o fazemos" (SCHÖN, 2000, p. 32). Schön $(1992,2000)$ ainda defende que o processo de reflexão-na-ação pode ser desenvolvido como uma sequência de "momentos", sutilmente combinados em uma habilidosa prática de ensino, como ilustrado na Figura 1.

Figura 1 - Esquema simplificado da concepção de prática reflexiva, segundo Schön, adaptado de Clarke (1994).

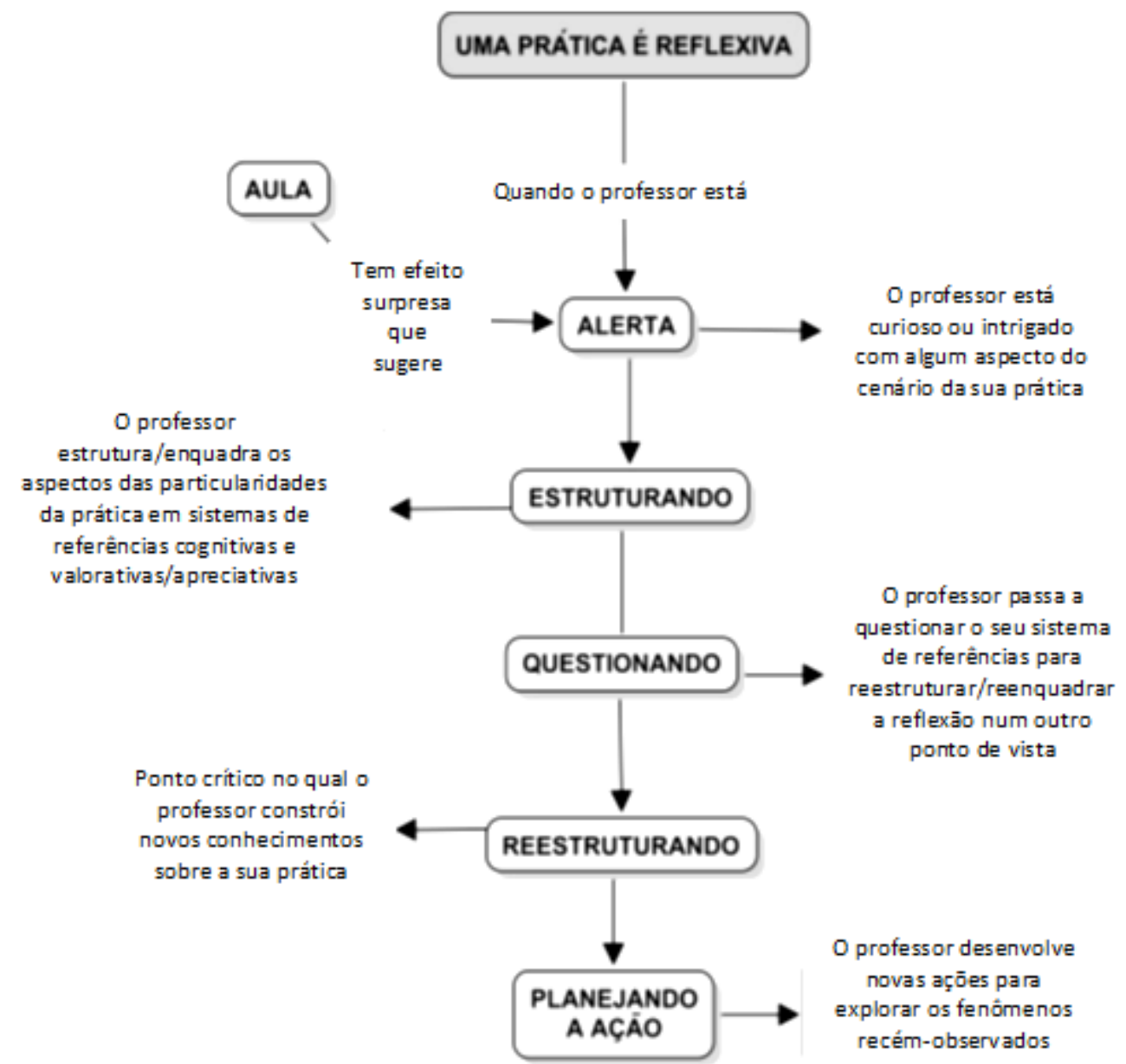

(Fonte: Rosa-Silva, 2008, p. 36) 
Alerta: refere-se a um momento de surpresa, "um professor reflexivo permite-se ser surpreendido pelo que o aluno faz" (SCHÖN, 1992, p. 83). Para essa situação, trazemos respostas espontâneas e de rotina, as quais revelam um processo de conhecer-na-ação, descrito como estratégias, compreensão de fenômenos ou formas de conceber um problema adequado à situação. $\mathrm{O}$ ato de conhecer-na-ação é um processo tácito e espontâneo, portanto, é um tipo de conhecimento revelado sem a deliberação consciente e que funciona enquanto a situação estiver ocorrendo da forma que aprendemos a tratar como normal (SCHÖN, 2000);

Estruturando: as repostas de rotina levam a um resultado inesperado, produzindo uma surpresa, agradável ou desagradável e que não se encaixa nas categorias de nosso conhecer-na-ação (SCHÖN, 2000). Nesse momento, o professor reflete sobre o fato que o intrigou, ou seja, pensa sobre aquilo que o aluno disse ou fez que Ihe causou surpresa e, simultaneamente, procura compreender a razão pela qual foi surpreendido (SCHÖN, 1992);

Questionando: a surpresa leva à reflexão consciente, ainda que não precise ocorrer por meio de palavras. Portanto, o professor reflete, levando em conta tanto o evento inesperado como o processo de conhecer-na-ação que levou a tal evento, perguntando-se: "o que é isso?"; "Como tenho pensado sobre isso?" (SCHÖN, 1992, 2000);

Reestruturando: O professor reformula o problema suscitado pela situação (SCHÖN, 1992). Por meio da reflexão-na-ação, a qual tem uma função crítica, questionamos a estrutura de pressupostos do ato de conhecer-na-ação e analisamos criticamente o pensamento que nos levou a essa situação difícil ou a essa oportunidade. Nesse momento, podemos reestruturar as estratégias de ação, as compreensões dos fenômenos ou as formas de conceber os problemas (SCHÖN, 2000);

Planejando a ação: nesse momento, o professor experimenta novas ações com o objetivo de explorar os fenômenos recém-observados, testar suas compreensões acerca deles ou, ainda, afirmar as ações que tenha inventado para mudar as coisas para melhor (SCHÖN, 2000). Portanto, "efetua uma experiência para testar a sua nova hipótese; por exemplo, coloca uma nova questão ou estabelece uma nova tarefa para testar a hipótese que formulou sobre o modo de pensar do aluno" (SCHÖN, 1992, p. 83).

A reflexão sobre a ação não tem qualquer relação com a ação presente e permite ao professor olhar retrospectivamente e refletir sobre a reflexão-naação, de modo a evidenciar como nosso ato de conhecer-na-ação pode ter contribuído para um resultado inesperado, agradável ou desagradável (SCHÖN, 1992, 2000). Segundo o autor, a reflexão sobre a reflexão-na-ação é uma ação, uma observação e uma descrição que exige o uso de palavras. Lorencini Jr. (2000) interpreta que: consideração o questionamento individual ou coletivo: dos procedimentos na fase de diagnóstico, da definição e determinação de metas, dos esquemas de pensamento, das teorias implícitas e formas de representar a realidade utilizada pelo professor nas situações problematizadas. Portanto, esse processo implica um conhecimento que analisa o conhecimento na ação e a reflexão na ação em relação à situação e seu contexto (LORENCINI JR., 2000, p. 29). 
Podemos proceder dessa forma após uma aula, em um ambiente de tranquilidade, no qual o professor pode pensar no que ocorreu; no que observou, e na eventual adoção de outros sentidos. Por isso, ao contrário da reflexão-naação e do conhecer-na-ação, os quais são processos que podemos desenvolver sem que precisemos dizer o que estamos fazendo, a reflexão sobre a reflexão-naação é uma ação, uma observação e uma descrição que exige o uso de palavras (Schön, 1992; 2000). Temos, portanto, que durante a realização de práticas de ensino, os estudantes podem refletir a respeito das diferentes situações e desafios que emergem da sua prática educativa e, serem estimulados a buscar soluções para problemas de ensino e de aprendizagem, o que pode levar à construção de conhecimento sobre o aprender a ensinar.

No entanto, Alarcão (2003) destaca a dificuldade que os sujeitos revelam em pôr em ação os mecanismos reflexivos, visto que para tal é preciso fazer um grande esforço, é preciso força de vontade e persistência. Para a autora, em um contexto formativo com base na experiência, a expressão e o diálogo assumem um papel de enorme importância, o que ela define como um triplo diálogo: um diálogo consigo próprio, com os outros, incluindo os que antes de nós construíram conhecimentos que são referência, e o diálogo com a própria situação. Logo, os formadores de professores têm um grande desafio e uma grande responsabilidade para com os seus estudantes: ajudá-los a desenvolver a capacidade de refletir de forma autônoma e sistematicamente em busca da resolução dos problemas práticos, o que os torna capazes de gerir a ação profissional (ALARCÃO, 2003).

Reconhecemos que os estudos de Schön acerca do profissional prático reflexivo apresentam ideias que, se incorporadas aos novos currículos das licenciaturas, podem contribuir favoravelmente para a formação de um profissional que saiba lidar com os desafios advindos principalmente das adversidades do contexto escolar.

Logo, propomos com esta investigação, realizar os processos de reflexão sobre a ação e reflexão sobre a reflexão-na-ação durante as atividades de microensino, desenvolvidas na disciplina de Estágio Supervisionado. Segundo Sant'Anna (1979) o microensino trata-se de um procedimento para a formação de professores que promove uma simulação da prática de ensino em situação de aprendizagem, um meio de praticar o ensino. No entanto, os autores Arrigo, Lorencini Jr. e Broietti (2017) entendem que neste contexto de preparação do estagiário, futuro professor, faz-se necessário buscar juntamente com o professor-formador e os colegas a superação de suas dificuldades e limitações por meio da reflexão sobre a sua prática.

Estes mesmos autores ainda defendem que o microensino deve estar fundamentado na epistemologia da prática, mesmo tendo surgido no período da racionalidade técnica. Assim, a forma de concebê-lo é que vai proporcionar aos estudantes, alunos das licenciaturas, a construção de um perfil docente pautado na reflexão. Portanto, no mesmo artigo, os autores destacam as potencialidades do microensino articulado a uma câmera de vídeo, de modo a integrá-lo ao procedimento da Autoscopia retratado por Bourron, Chaduc e Chauvin (1998 apud Fernandes, 2004). Estas proposições deram origem a uma estratégia de coleta de dados e intervenção reflexiva denominada Autoscopia Bifásica, que permitiu aos estudantes o desenvolvimento da auto-observação e da autocrítica 
por meio da reflexão a respeito da sua ação junto aos colegas e ao professorformador (ARRIGO, LORENCINI JR. e BROIETTI, 2017).

Desse modo, nesta investigação adotamos a Autoscopia Bifásica como procedimento para a coleta dos dados e posteriormente como estratégia de intervenção reflexiva na formação inicial de professores de Química. Nas seções seguintes, descrevemos o contexto em que implementamos os procedimentos metodológicos desta investigação, bem como, o percurso analítico realizado para analisar e interpretar o conteúdo das reflexões dos estudantes, sujeitos desta pesquisa.

\section{ENCAMINHAMENTO METODOLÓGICO}

Esta pesquisa foi realizada em um curso de Licenciatura em Química de uma Instituição privada de Ensino Superior. Nesta instituição, as atividades de microensino são desenvolvidas nas disciplinas de Estágio Supervisionado I e II, as quais ocorrem no 70 e 8 o período do referido curso, respectivamente. A turma em que implantamos a proposta era composta por 19 estudantes com faixa etária entre 22 a 36 anos, pertencentes ao 8o período (semestre).

Ao longo do semestre, filmamos os microensinos desenvolvidos nos meses de agosto e novembro. Pelo fato de passarmos a aula toda realizando as filmagens, foi necessário interrompê-las para dar início a realização das intervenções reflexivas, e, desse modo, foi possível filmarmos os microensinos de 11 dos 19 estudantes da turma, totalizando 22 aulas. Considerando que o curso é ofertado no período noturno e que muitos estudantes não residiam na cidade em que foi realizada a coleta de dados, realizamos a intervenção reflexiva com 7 dos 11 estudantes registrados.

$\mathrm{Na}$ fase pós-ativa foram realizadas as intervenções reflexivas com os estudantes e as discussões ocorridas a respeito dos seus respectivos microensinos foram gravadas em áudio para posterior transcrição. Assim sendo, transcrevemos as discussões para analisar o conteúdo das reflexões dos estudantes. Contudo, para este artigo, selecionamos as transcrições provenientes da intervenção reflexiva realizada com três estudantes. Para garantir o anonimato dos sujeitos analisados, referimo-nos a eles como Liz, Zeca e Gisa. Na sequência apresentamos uma breve contextualização dos sujeitos.

Liz teve uma experiência de regência de aulas anterior ao microensino. Para Liz, a opção pelo curso de Licenciatura em Química ocorreu por acreditar que seria fácil conseguir um emprego na área, além do fato de gostar do conteúdo de Química Orgânica, nas aulas do Ensino Médio. Liz menciona em uma das entrevistas que o fato de ter que realizar o estágio de regência e ministrar aulas para os colegas no microensino a deixou assustada, mas que isso, mesmo assim serviu para que percebesse que gostava de ministrar aulas.

Zeca, o segundo estudante analisado, menciona interesse pelo curso pela possibilidade de atuar também na indústria. Contudo, ao realizar os estágios supervisionados na escola percebeu que ensinar era muito gratificante, apesar do receio em falar em público.

Gisa, nossa terceira estudante, relatou que desde pequena sentia vontade de ser professora, por isso fez Magistério e, logo em seguida, iniciou o curso de 
Licenciatura em Química. No decorrer do curso, participou de projetos de pesquisa, voltados para a área de alimentos o que a fez se interessar mais pelas pesquisas desenvolvidas em laboratório do que pela área de ensino de Química.

Para identificarmos e analisarmos o conteúdo das reflexões dos estudantes ao longo das atividades de microensino fizemos uso da Autoscopia Bifásica, estratégia de intervenção reflexiva que permitiu a realização dos processos de reflexão sobre a ação e reflexão sobre a reflexão-na-ação, motivo pelo qual não foi necessária a participação da fase pré-ativa.

Figura 2 - Esquema da autoscopia bifásica realizada com os estudantes de um curso de Licenciatura em Química.

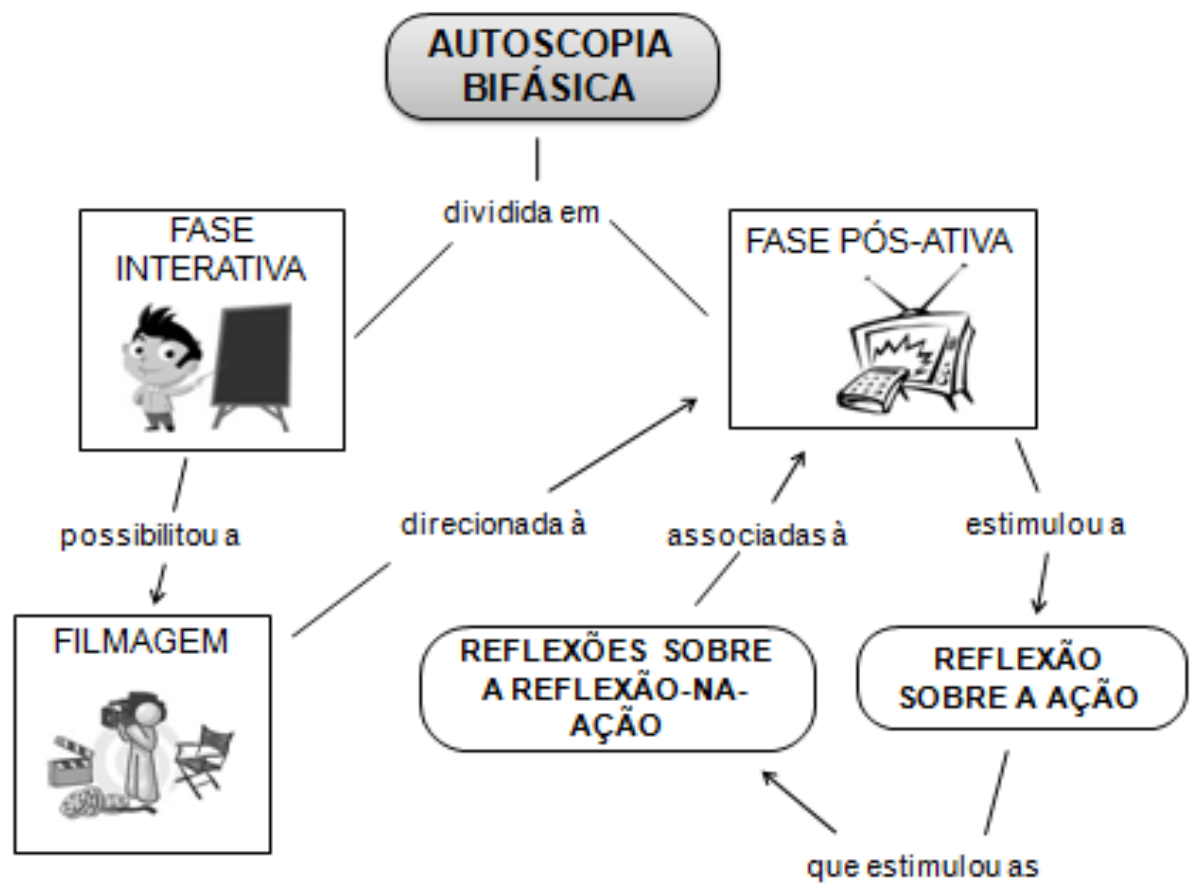

(Fonte: Arrigo, 2015, p. 53)

\section{A AUTOSCOPIA BIFÁSICA}

Assim como Rosa-Silva (2008), inspiramo-nos no modelo proposto por Jackson (1968 apud Saint-Onge, 2001) para a elaboração da Autoscopia Bifásica, procedimento utilizado para a coleta de dados e intervenção reflexiva com os estudantes. De acordo com esse modelo, o autor sugere agrupar as atividades de ensino realizadas pelos estudantes, futuros professores, em torno de três fases: a pré-ativa, a interativa e a pós-ativa. Entretanto, nessa investigação, nos restringimos somente às fases: interativa e pós-ativa, uma vez que não participamos da fase pré-ativa, conforme esquematizado na Figura 2.

A fase pré-ativa é descrita por Jackson (1968 apud Saint-Onge, 2001) como o momento em que o professor deve planejar sua aula e preparar os instrumentos necessários para sua realização. Essa fase, na qual os estudantes planejam a sua ação e delimitam os recursos a serem utilizados durante o microensino, possibilita a realização de reflexões para ação. Nesta investigação, tivemos 
foi entregue à professora-formadora no início de cada microensino; não participamos do planejamento.

A professora-formadora responsável pela disciplina orientou cada estudante para a elaboração do microensino, realizando correções nos planos de aula, sugerindo possíveis estratégias de ensino que poderiam ser empregadas para favorecer a aprendizagem, bem como leituras e referenciais que os auxiliassem no preparo das aulas. O conteúdo ministrado foi sorteado no primeiro dia de aula da disciplina de Estágio Supervisionado pela professora-formadora, os quais foram também por ela selecionados com base em conceitos centrais da disciplina de Química, tais como: Fenômenos Físicos e Químicos e Estados Físicos da Matéria; Carbono e seus compostos; Equilíbrio Químico; Funções Inorgânicas: ácidos e bases; Ligações Químicas; Modelos atômicos e características dos átomos, entre outros.

A fase interativa, segundo Jackson (1968 apud Saint-Onge, 2001) refere-se à condução do processo de ensino em sala de aula, por meio do qual o professor estabelece interações com os alunos e guia sua aprendizagem. Nessa fase, os estudantes tiveram 30 minutos para conduzir o microensino com base no que haviam planejado durante a fase pré-ativa. Ao nos posicionarmos sempre na primeira carteira do canto direito da sala de aula, participamos dessa fase realizando a filmagem das ações dos estudantes na posição de pesquisadorformador. Como já mencionado anteriormente, segundo Schön $(1992,2000)$ a reflexão-na-ação supõe uma atividade cognitiva consciente do sujeito, realizada enquanto se está atuando, ou seja, o professor reage a uma situação de indeterminação prática e tenta solucioná-la por meio de um diálogo reflexivo consigo mesmo. Por isso, trata de uma atividade que não exige o uso de palavras, o que torna impossível o registro destas reflexões, que somente tivemos acesso na fase pós-ativa, quando os estudantes realizaram reflexões sobre a reflexão-naação, sendo esta uma descrição que exige o uso de palavras.

A fase pós-ativa, segundo Jackson (1968 apud Saint-Onge, 2001) compreende o momento em que o futuro professor avalia os resultados do processo de ensino, visando modificar a sua preparação em função da avaliação. Nessa fase, assistimos as cenas de cada microensino e selecionamos as que apresentavam a ocorrência de situações que interpretamos como sendo inesperadas, como, por exemplo: questionamentos feitos pelos alunos ou pela professora-formadora; o estudante ser avisado que o tempo estava se esgotando; falta de tempo para dar conta de tudo o que havia planejado; o nervosismo e/ou a insegurança quando presentes; dúvidas em torno do momento "correto" para a realização de atividades experimentais; o surgimento de dificuldades para se trabalhar o conteúdo; e até mesmo dificuldade em relação ao conteúdo propriamente dito.

A partir das cenas selecionadas, procedemos com a realização da intervenção reflexiva, com a utilização de um roteiro norteador composto por questões como: Explique como você planejou a sua aula; quais as dificuldades e facilidades que você encontrou no planejamento da aula? Quando terminou a aula, você considerou que os objetivos foram alcançados? A aula ocorreu de acordo com o que você planejou? Ocorreu algo inesperado? Como foi a aula na sua concepção? $O$ que você pensava, refletia, enquanto estava ministrando a aula? Você sentiu dificuldades no processo de ensino? Como você pretende resolver essas dificuldades? Como você se sentiu assistindo a sua própria aula? 
Qual é a sua avaliação sobre este encontro? Você acha que assistir o vídeo contribuiu para a sua formação?

Ao assistirem o vídeo, os estudantes então puderam reconstruir as cenas do seu microensino e com a utilização do roteiro norteador, foram estimulados a refletir sobre a ação, que por sua vez os impulsionavam a refletir sobre a reflexão-na-ação. As discussões foram gravadas em áudio para posterior transcrição. Ao inserirmo-nos no contexto desta pesquisa, registramos as informações por meio de anotações, filmagens e gravações em áudio, a fim de interpretá-las pela análise indutiva, conforme os dados foram se agrupando. Portanto, esta investigação apresenta uma abordagem de cunho qualitativo, ou seja, nosso interesse é priorizar os processos, não somente o que acontece, mas como ocorrem (BOGDAN e BIKLEN, 1994).

\section{APRESENTAÇÃO DOS DADOS E DISCUSSÃO DOS RESULTADOS}

A partir do surgimento de um elemento surpresa, ou seja, algo que não está previsto com as nossas expectativas e que o nosso ato espontâneo de conhecerna-ação não nos permite solucionar, podemos realizar reflexão-na-ação ou sobre $a$ ação. A reflexão-na-ação é um processo que não exige o uso de palavras e ocorre no meio da ação, sem interrompê-la. Ao contrário, a reflexão sobre a ação não tem qualquer relação com a ação presente e permite ao professor olhar retrospectivamente e refletir sobre a reflexão-na-ação, podendo revelar como nosso ato de conhecer-na-ação pode ter contribuído para um resultado inesperado, agradável ou desagradável (SCHÖN, 1992, 2000).

Assim, devido a impossibilidade de capturar as reflexões na ação, ou seja, o que os estudantes estavam pensando durante a ação (durante o microensino), nosso ponto de partida para a identificação das reflexões de Liz, Zeca e Gisa, constituiu-se pelas reflexões sobre a ação que estes realizavam a medida que o vídeo era por eles assistido.

Como a reflexão sobre a reflexão-na-ação é uma ação, uma observação e uma descrição que exige o uso de palavras, instigamos os estudantes a refletirem sobre as suas reflexões, com a intenção de captarmos as suas impressões a respeito da sua prática de ensino. Este procedimento permitiu a Liz, Zeca e Gisa aprofundarem as suas reflexões e pensarem sobre o que refletiram ao planejar e ministrar o microensino. Este movimento nos permitiu ter acesso as reflexões sobre a reflexão-na-ação realizada por eles, as quais, por sua vez, compõem os dados analisados nesta investigação.

Como menciona Schön (2000), o processo de reflexão-na-ação pode ser desenvolvido em uma sequência de "momentos", denominados alerta, estruturação, questionamento, reestruturação e planejamento da ação. Logo, por meio do processo de reflexão sobre a reflexão-na-ação, buscamos primeiramente identificar, nas falas dos estudantes, situações decorrentes das suas práticas de ensino que os levaram a se colocar em posição de alerta, ou seja, elementos surpresa que emergiram durante o microensino, os quais denominamos alerta 1 , alerta 2, alerta 3, assim por diante.

Em seguida, delimitamos o alerta recorrente ou o alerta que desencadeou os estudante os levou a refletir sobre a reflexão-na-ação, que por sua vez 
possibilitou a exposição do problema com o qual se deparou, questionando e reestruturando a sua prática de ensino com base no seu conhecimento-na-ação.

Ao realizarmos a análise do conteúdo das reflexões de Liz, Zeca e Gisa, conforme descrito, tivemos acesso ao conteúdo das suas reflexões e pudemos interpretar a sua prática reflexiva baseando-nos nos "momentos" reflexivos descritos por Schön $(1992,2000)$. Na sequência apresentamos e discutimos as reflexões de Liz, Zeca e Gisa, analisadas e interpretadas de acordo com a epistemologia dos "momentos" reflexivos descritos por Schön $(1992,2000)$, a partir das cenas previamente selecionadas.

\section{As reflexões de Liz}

A partir da análise e interpretação do conteúdo das reflexões de Liz, identificamos em suas falas quatro momentos em que a estudante se colocou em estado de alerta frente a alguma situação decorrente da sua prática de ensino. Na Tabela 1 apresentamos uma síntese de tais situações.

Tabela 1 - As situações de alerta originadas da prática reflexiva de Liz.

Conteúdo do microensino: Nomenclatura dos hidrocarbonetos

\begin{tabular}{|c|c|c|}
\hline & Falas & Interpretação \\
\hline 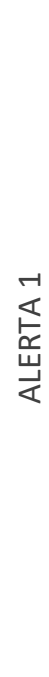 & $\begin{array}{c}\text { "Eu preparei a aula, mas não sabia ainda } \\
\text { se começava dos hidrocarbonetos ou se } \\
\text { eu começava falando das cadeias } \\
\text { separando as estruturas. Então, eu } \\
\text { pensei: vou começar separando as } \\
\text { estruturas e se caso a professora- } \\
\text { formadora falasse olha não é o tema ou, } \\
\text { você pode já entrar nos hidrocarbonetos, } \\
\text { eu já tinha preparado ali. Agora se eu } \\
\text { começasse dos hidrocarbonetos e } \\
\text { alguém perguntasse: mas como eu vou } \\
\text { saber se é uma cadeia simples ou } \\
\text { ramificada? Então eu já comecei dessa } \\
\text { parte porque é o que se deve começar a } \\
\text { passar mesmo, e não direto a } \\
\text { nomenclatura”. }\end{array}$ & $\begin{array}{l}\text { Liz demonstrou dificuldade em relação a } \\
\text { como abordar o conteúdo, deixando } \\
\text { claro que não sabia se deveria iniciá-lo } \\
\text { pelas regras de nomenclatura dos } \\
\text { hidrocarbonetos ou pela classificação } \\
\text { das cadeias carbônicas. Cabe salientar } \\
\text { ainda que esse foi o alerta recorrente } \\
\text { nas falas da estudante, sendo } \\
\text { comentado por ela antes da passagem } \\
\text { do vídeo e por mais três vezes ao longo } \\
\text { da discussão com a pesquisadora. } \\
\text { Interpretamos que o mesmo foi o } \\
\text { responsável por desencadear os alertas } \\
\text { seguintes e por isso a estudante sentiu a } \\
\text { necessidade de reestruturá-lo com base } \\
\text { na sua prática reflexiva. }\end{array}$ \\
\hline
\end{tabular}


"Eu acredito que não, a não ser que eu lembrasse durante a aula. Para mim era uma dúvida como um aluno qualquer 'eu estou tendo uma dúvida'. Porque é aquilo que eu falei, pra gente é tão comum, é uma coisa tão simples. Lógico que para um aluno do ensino médio não é simples, mas pra gente é tão comum que às vezes; nossa, é verdade, eu tinha que ter falado! Só na hora que perguntaram eu pensei: nossa, eu realmente deveria ter falado dos hidrocarbonetos; mas é aquilo que eu falei, talvez ao longo da aula eu chegaria a falar: olha isso aqui é um hidrocarboneto, mostrando uma estrutura de carbono e hidrogênio".

"Eu preparei a aula até os alcadienos, mas eu tinha certeza que não ia dar tempo de chegar neles. Então, eu queria passar o que eu sabia que ia dar tempo de fazer, porque se eu colocasse os alcadienos e não desse nenhum exemplo, eles iam me cobrar".

"Então, de acordo com o que eles faziam na aula, eu ficava tentando buscar, mas ali [no microensino] é como se eu desse aula para as paredes. De certa forma, eu seguia um roteiro, porque não tem tantas perguntas, não tem que ficar conquistando a sala, chamando a sala para a aula, porque, qualquer pergunta que eu fizesse, todo mundo me daria a resposta certa, então não tem discussão".
Liz também refletiu a respeito do questionamento feito por um colega da turma em relação à definição de hidrocarbonetos. Ela reconheceu que deveria tê-los definido no início da aula, porém, sanou a dúvida do colega de uma forma que todos pudessem compreender, sem comprometer o desenvolvimento do microensino. Logo, percebemos que este momento de alerta, apesar de levado a estudante a refletir, não a fez sentir necessidade de reestruturá-lo.

Como Liz já havia previsto anteriormente, a professora-formadora realmente a interrompeu e questionou o conteúdo que ela estava trabalhando, sendo necessário que ela apagasse o quadro e iniciasse a aula novamente. Então, ela refletiu sobre o tempo de duração do microensino, visto que o cronômetro já marcava 13 minutos de aula. Logo, ela optou por não comentar sobre os alcadienos por receio de não conseguir trabalhar as quatro classes dos hidrocarbonetos nos 17 minutos restantes.

Ao refletir sobre a interação professoraluno, a estudante faz uma comparação do microensino com o seu estágio de regência. Liz conta que também trabalhou o conteúdo de hidrocarbonetos no seu estágio, dias após a realização do microensino, ressaltando que na sala de aula real havia interação, sendo possível trabalhar com as dificuldades dos alunos, o que ela afirmou não ocorrer no microensino.

Compreendemos que o tempo, a falta de interação professor-aluno, a intervenção da professora formadora e o questionamento feito pelo colega contribuíram para que Liz ficasse ainda mais confusa durante a aula, sem saber se explicava sobre a classificação das cadeias ou sobre a nomenclatura dos hidrocarbonetos. Entretanto, entendemos que o fato de ela ter ficado confusa não advém de uma dificuldade em relação ao conteúdo, mas de como trabalhálo. Portanto, percebemos que o 2으, о 3 o e o 4ㅇ "momentos" de alerta apresentados, contribuíram para a recorrência do alerta 1 ao longo do percurso das nossas discussões. 
Sendo assim, a partir do "momento" de alerta recorrente durante a sua prática de ensino, identificamos nas falas de Liz os "momentos" de estruturação, questionamento, reestruturação e planejamento de uma nova ação, e assim, elaboramos um esquema da sua prática reflexiva, representado pela Figura 3.

Figura 3 - Esquema dos "momentos" reflexivos de Liz, segundo Schön (1992, 2000), adaptado de Clarke (1994).

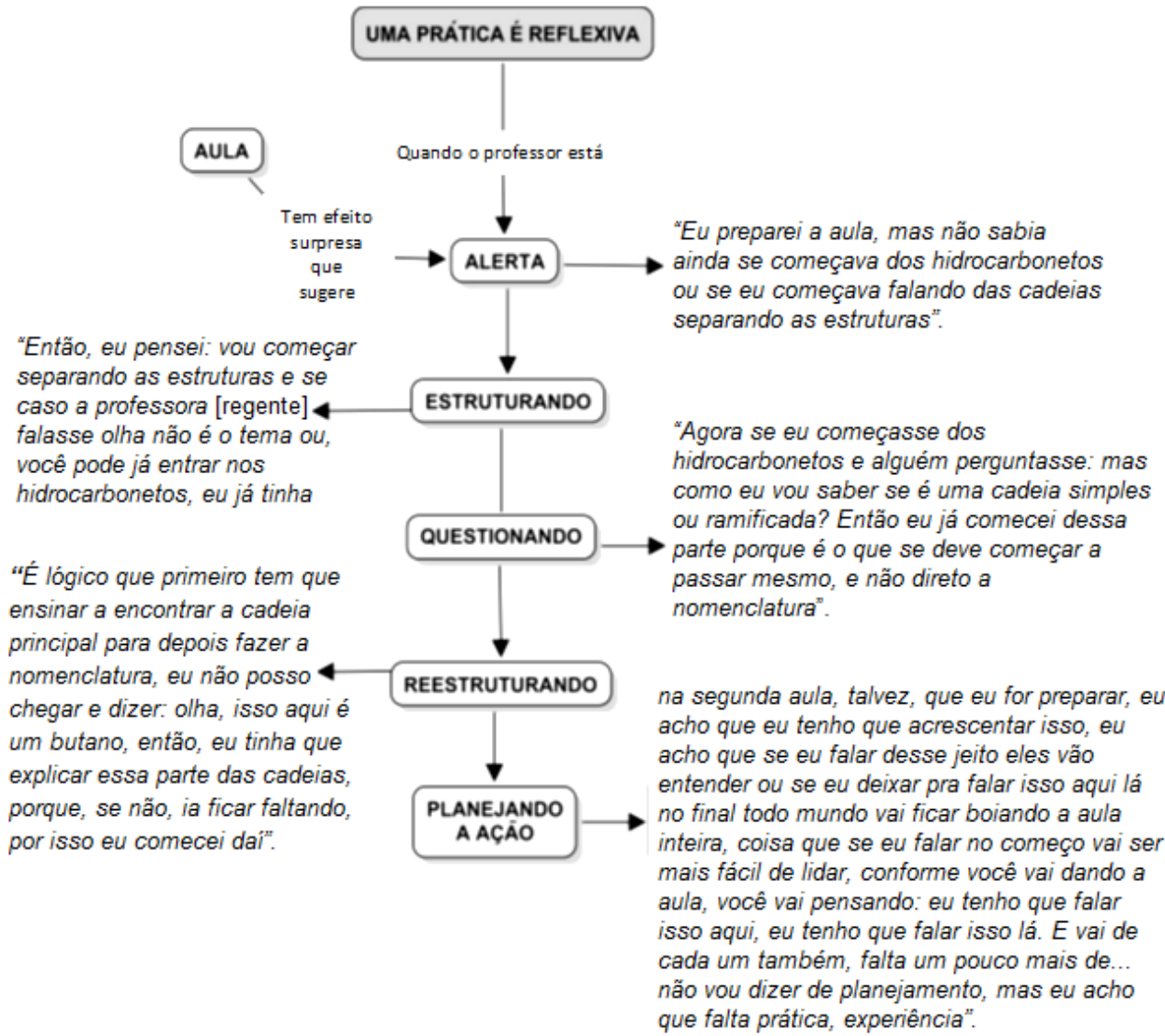

(Fonte: Arrigo, 2015, p. 75)

De acordo com Schön (2000), compreendemos que as reflexões realizadas por Liz levaram a pensar em como o seu ato de conhecer-na-ação pode ter contribuído para a ocorrência dos problemas identificados em sua prática de ensino, os quais classificamos como alertas. Com base no esquema da sua prática reflexiva, identificamos que ela se deparou com uma situação-problema durante o planejamento do seu microensino; situação essa que interpretamos embasados em Schön (2000), como não ter enquadrado esse problema nos moldes do que aprendeu a tratar como normal. Portanto, foi necessário estabelecer um diálogo reflexivo com a situação educativa para configurar tal problema por meio de uma resposta que não fosse rotineira e espontânea.

Assim, em um momento de estruturação, Liz toma a decisão de iniciar o conteúdo pela classificação das cadeias carbônicas na confiança de que a professora-formadora avisaria durante a aula se esse não fosse o conteúdo do seu microensino. Interpretamos que, nesse momento, ela expõe o problema por meio de uma resposta de rotina. No entanto, toda resposta de rotina leva a um resultado inesperado, produzindo uma surpresa agradável ou desagradável (SCHÖN, 1992, 2000). 
Desse modo, Liz questiona o seu sistema de referências em relação à decisão tomada e tenta justificar pensando em uma possível pergunta que pudesse vir de algum aluno durante a aula. No decorrer do microensino de Liz, a professoraformadora realmente intervém dizendo que o conteúdo que ela deveria trabalhar não era a classificação das cadeias, o que leva a estudante a apagar todo o quadro e a iniciar o conteúdo da classificação dos hidrocarbonetos, necessário à realização da nomenclatura desses compostos.

Por isso, em um momento de reestruturação, Liz pensa criticamente na sua dúvida durante o planejamento e na decisão tomada em iniciar o conteúdo pela classificação das cadeias. Com base em Schön (2000), interpretamos que essas circunstâncias a levaram a questionar a sua estrutura de pressupostos do ato de conhecer-na-ação, bem como as suas estratégias de ensino.

Após reestruturar as suas estratégias de ação, admitimos que Liz reconhece os problemas decorrentes da sua prática de ensino, provenientes de sua dificuldade em abordar o conteúdo, a qual constatamos não advir do conhecimento do conteúdo propriamente dito, mas de como apresentá-lo aos estudantes. Por fim, em um momento de planejamento da ação, Liz pensa em novas ações para melhorar a sua prática de ensino. Apesar de não citar quais seriam as mudanças necessárias para essa nova ação ou próxima aula; entendemos pela sua fala que ela está se referindo à forma como organizará e apresentará o conteúdo da nomenclatura dos hidrocarbonetos.

\section{As reflexões de Zeca}

A partir da análise e interpretação do conteúdo das reflexões de Zeca, identificamos em suas falas três momentos em que o estudante se colocou em estado de alerta frente a alguma situação decorrente da sua prática de ensino. Na Tabela 2 apresentamos uma síntese de tais situações.

Tabela 2 - As situações de alerta originadas da prática reflexiva de Zeca.

Conteúdo do microensino: Ácidos e Bases

Falas

\begin{tabular}{c}
\hline Falas \\
\hline \\
"Então, na verdade você começa a ver \\
alguns erros primeiramente, que você faz \\
porque se está nervoso, é uma pressão, \\
sei lá, não dá para explicar. Porque você \\
conhece todo mundo, você tenta dar \\
$\stackrel{\square}{\Psi}$ aula, explicar tudo certinho e acaba não \\
saindo certo, aí você começa a se \\
apavorar, apavorar... mas também foi só \\
nessa aula aí, porque na outra eu fui \\
bem até".
\end{tabular}

\section{Interpretação}

O nervosismo de Zeca ficou evidente durante o microensino, tanto que ao iniciarmos a passagem do vídeo, ele rapidamente começou a refletir sobre como se sentiu pressionado e intimidado por estar ministrando aula para os próprios colegas de turma. Ainda nessa fala, o estudante tenta se justificar quando compara esse microensino com o realizado no primeiro semestre da disciplina, do qual não participamos. Assim, observamos que o estudante ficou atento para o seu estado emocional, quando afirma ter se sentido "apavorado". Logo, interpretamos que o nervosismo de Zeca foi desencadeado por insegurança em relação ao conteúdo a ser ensinado. 
"Nessa aula aí não! Porque eu passei as coisas meio desordenadas. Eu deveria ter

falado só de ácidos primeiro ou ácidos e bases dando uma explicação contextualizada; e eu não coloquei coisas do cotidiano, deveria ter feito isto para depois falar de $\mathrm{HCl}, \mathrm{NaOH}$, essas coisas, definir mesmo ácidos e bases".

"Então, o planejado era dar ácidos $e$ bases, tanto é que eu dei, só não ficou do jeito que eu imaginava".

"Primeiro, eu comecei a me perder porque eu estava nervoso, eu montei, assim, sei lá se foi muito correndo, eu não pensei como iria ser o desenvolvimento da aula, aí eu comecei a me apavorar".
Verificamos que a sua insegurança advém do conteúdo propriamente dito, mais precisamente da dificuldade encontrada em expô-lo e trabalhá-lo de forma clara. Portanto, observamos que Zeca relata o problema com o qual se deparou durante a sua prática de ensino.

Zeca deixa claro que não pensou em como seria o desenvolvimento da sua aula, logo, constatamos que esse foi o motivo que o fez sentir-se inseguro quando se viu à frente da sala de aula na posição de professor, chegando a pensar até em desistir. Identificamos nesse instante uma lacuna presente no seu planejamento, gerada pelo fato de o estudante não ter refletido durante a sua elaboração, o que pode ter limitado sua prática de ensino no que diz respeito à organização e a exposição do conteúdo. Sendo assim, constatamos que a sua dificuldade em relação ao conteúdo advém do seu planejamento, pois foi elaborado sem a realização de reflexão para ação.

(Fonte: Os autores)

Percebemos que Zeca planejou seu microensino sem refletir para ação, o que comprometeu o desenvolvimento da sua aula e desencadeou as situaçõesproblema identificadas: a dificuldade para apresentar o conteúdo, advinda da deficiência em relação a alguns conceitos de ácidos e bases, o que, por sua vez, levou-o a se sentir inseguro, fazendo com que permanecesse nervoso durante toda aula.

Admitimos que o alerta 3, referente ao seu planejamento, foi o responsável por desencadear os alertas 1 e 2 , decorrentes da sua prática de ensino. Foram identificados nas falas de Zeca durante a discussão, três "momentos" de reestruturação da sua prática de ensino, nos quais ele pensa em como foi apresentado o conteúdo de ácidos e bases e, em seguida, replaneja sua aula pensando em como poderia ter ministrado, de modo a melhorar a sua prática para disponibilizá-la em ações futuras. Sendo assim, para a escolha de uma dessas falas, optamos pela que foi proferida ao final da discussão, instante em que Zeca já havia refletido sobre todas as situações-problema ocorridas no decorrer de sua aula.

Assim sendo, após selecionarmos a fala referente à reestruturação da sua prática de ensino, também identificamos um "momento" de estruturação e outro de questionamento a partir do alerta 3, os quais foram utilizados para elaborar o esquema da sua prática reflexiva, representado pela Figura 4. 
Figura 4 - Esquema dos "momentos" reflexivos de Zeca, segundo Schön (1992, 2000), adaptado de Clarke (1994).

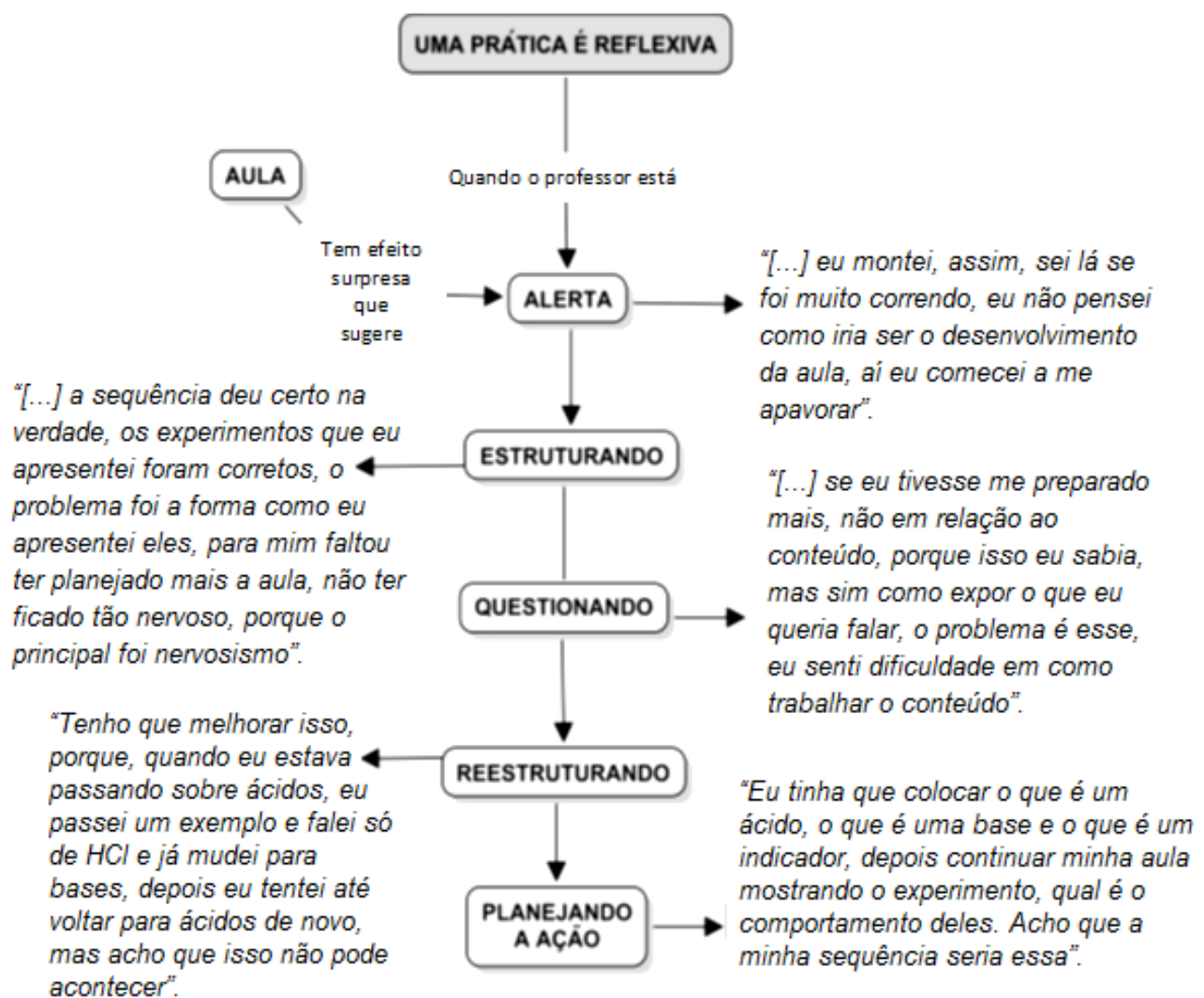

(Fonte: Arrigo, 2015, p. 90)

As discussões realizadas com Zeca e o esquema da sua prática reflexiva indicam que ele não realizou o movimento de reflexão para ação quando mencionou que não pensou em como seria o desenvolvimento da sua aula, fato que interpretamos como sendo um problema da sua prática de ensino, classificado como o alerta 3. Identificamos, também, que o alerta 3 foi o responsável por desencadear os demais, ou seja, a falta de planejamento ocasionou a dificuldade em trabalhar o conteúdo, que, por sua vez, interpretamos advir de algumas deficiências em relação ao assunto discutido, levando o estudante a sentir-se inseguro, permanecendo nervoso durante a aula. $O$ fato de o alerta 3 ter desencadeado os alertas 1 e 2 evidencia um resultado de causa e efeito de fatores interdependentes, mesmo que cronologicamente durante as discussões da fase pós-ativa, os alertas 1 e 2 antecedem o 3.

Podemos observar, no esquema da prática reflexiva de Zeca, que ele se deparou com uma situação-problema logo no início do microensino, quando se deu conta de que havia preparado a aula de forma apressada, sem a realização de reflexão para ação. Logo, a aula não ocorreu conforme o planejado, e, portanto, a situação não se enquadrou dentro dos limites do que aprendeu a tratar como normal (SCHÖN, 2000). Em um momento de estruturação, ao expor o problema, ele tenta interpretá-lo, quando diz que a sequência e os experimentos planejados deram certo, mas que o problema foi a falta de organização das atividades por não as ter planejado adequadamente, o que o fez 
sentir-se nervoso, fato que interpretamos, de acordo com Schön (2000), como sendo uma resposta de rotina.

Como toda resposta de rotina leva a um resultado inesperado, produzindo uma surpresa agradável ou desagradável, interpretamos que Zeca questionou-se dizendo: "se eu tivesse me preparado mais". Porém, ao ter consciência que a aula não ocorreu como havia planejado, tentou justificar-se dizendo que o conteúdo não era um problema, e sim a forma como deveria apresentá-lo. Ao assistir o seu microensino e a partir da análise das nossas discussões, constatamos que Zeca ainda apresentava algumas deficiências referentes aos conceitos de ácidos e bases e, por isso, sentiu-se inseguro durante a aula.

Assim, em um momento de reestruturação, ele pensa criticamente sobre a forma como conduziu a aula e como organizou o conteúdo, o que nos leva a interpretar, mais uma vez, que a falta de planejamento e de conhecimento do conteúdo fez com que ele se deparasse com os problemas identificados e discutidos. Por isso, a partir das ideias de Schön (2000), interpretamos que esses problemas o levaram a questionar a sua estrutura de pressupostos do ato de conhecer-na-ação, bem como as suas estratégias de ensino, pensando em uma forma de melhorar a sua prática de ensino em ações futuras. Ao planejar uma nova ação, notamos que Zeca ainda sente a necessidade de estabelecer uma sequência para trabalhar os ácidos e as bases, o que pode ser explicado pela dificuldade em relação ao conteúdo, que acaba limitando a sua reflexão a respeito de possíveis situações-problema que possam emergir durante a aula.

Interpretamos, também, que, apesar de o estudante ter reconhecido os problemas da sua prática, ainda se faz necessário a reflexão para ação com base nas reflexões sobre a reflexão-na-ação, o que, segundo Schön (1987 apud ALARCÃO, 1996), é um processo que leva o professor a progredir no seu desenvolvimento e a construir a sua forma pessoal de conhecer, auxiliando na compreensão dos problemas ou na descoberta de soluções para eles.

\section{As reflexões de Gisa}

A partir da análise e interpretação do conteúdo das reflexões de Gisa, identificamos em suas falas dois momentos em que a estudante se colocou em estado de alerta frente a alguma situação decorrente da sua prática de ensino. Na Tabela 3 apresentamos uma síntese de tais situações.

Tabela 3 - As situações de alerta originadas da prática reflexiva de Gisa.

Conteúdo do microensino: Processos de separação de misturas 
"Eu fiquei na dúvida na hora de fazer o experimento, se eu fosse fazer antes ou durante. Eu acho que o correto seria fazer durante. Por exemplo, falar sobre a centrifugação e ter como mostrar aquele processo e não no final como uma comprovação da teoria. Então eu queria estar fazendo contínuo, mostrando o processo e mostrando como ele acontece".

"Eu acho que com a prática e a teoria juntas eles aprendem mais do que se for só passando a teoria no quadro e deixando pra eles copiarem, pois com a gente acontece isso também, imagina com aluno do ensino médio".

"É verdade. Ainda mais que eu não escrevi as definições antes, mas tem a falta de tempo também, eu fiquei com medo de não dar tempo de dar tudo e

"Do conteúdo sim, só faltou uma parte do vídeo, mas da parte teórica eu consegui dar tudo, faltaram os exercícios, essa parte mesmo, mas o teórico eu dei tudo".
Observamos que Gisa se colocou em estado de alerta em relação ao momento de realização do experimento, visto que ela expôs o problema com o qual se deparou ao refletir sobre a forma como gostaria de ter conduzido a sua aula. Assim, percebemos que suas dúvidas a respeito do momento de realização do experimento surgiram da ideia de que o correto seria realizá-lo durante a aula, por meio da articulação entre teoria e prática.

Além disso, a segunda fala da estudante expressa claramente a sua preocupação com o aprendizado dos alunos, o que interpretamos ter desencadeado as suas dúvidas e limitações sobre o momento e a forma de desenvolver a atividade experimental.

Logo, surgiu um segundo momento em que a estudante se colocou em estado de alerta, demonstrando uma inquietação em relação ao tempo de duração do microensino, o que a levou a trabalhar a parte teórica do conteúdo de forma apressada e superficial para que fosse possível a realização do experimento como ela havia planejado.

\section{(Fonte: Os autores)}

O fato de o experimento ter ficado para o final da explanação teórica sobre o conteúdo levou Gisa a atentar-se para o tempo de duração do microensino. Logo, interpretamos que a sua inquietação em relação à duração do microensino advém da sua ânsia em realizar o experimento.

Desse modo, admitimos que o alerta 1 foi o responsável por desencadear o alerta 2 , ou seja, a sua dúvida em relação ao momento de realização da atividade experimental fez com que a estudante ficasse alerta, durante a aula, em relação ao tempo disponível, levando-a a apresentar a parte teórica do conteúdo de forma apressada. Sendo assim, a partir do alerta 1, identificamos os "momentos" de estruturação, questionamento, reestruturação e planejamento de uma nova ação, utilizados para a elaboração do esquema da sua prática reflexiva, representado pela Figura 5. 
Figura 5 - Esquema dos "momentos” reflexivos de Gisa, segundo Schön (1992, 2000), adaptado de Clarke (1994)

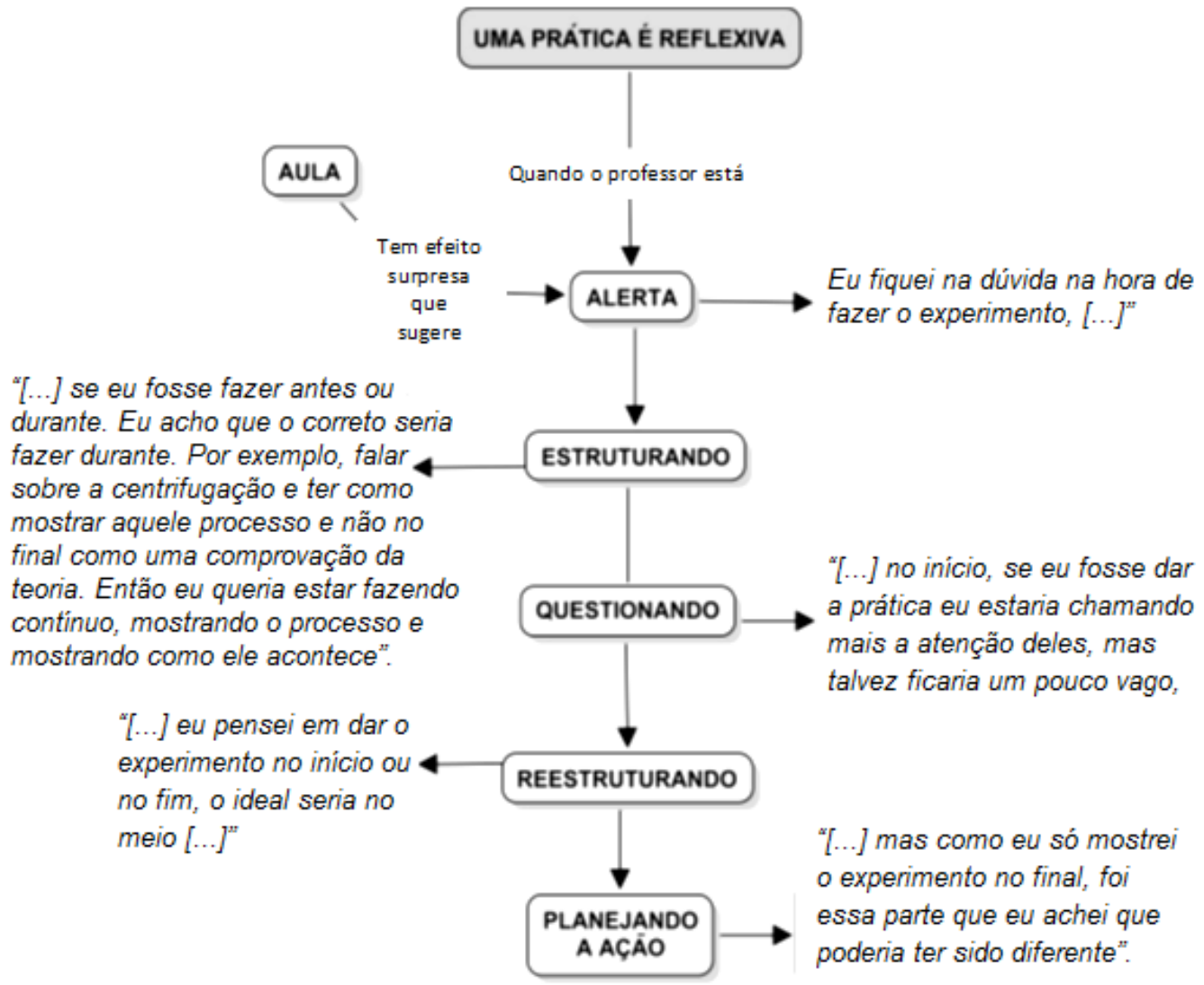

(Fonte: Arrigo, 2015, p. 102)

Durante a realização da intervenção reflexiva com Gisa, percebemos que ela se mostrou resistente em reconhecer e discutir a respeito dos problemas identificados em sua prática de ensino, realizando, na maioria das vezes, reflexões sobre a ação. Apesar de ela ter se apresentado resistente durante a discussão, foi possível observarmos que ela realizou reflexões para ação durante o planejamento do seu microensino, às quais tivemos acesso somente na fase pós-ativa, e por isso as classificamos como sendo reflexões sobre a reflexão para ação.

Percebemos que a sua inquietação em relação ao tempo (alerta 2) advém da sua preocupação com o momento de realização do experimento (alerta 1), visto que, durante a nossa discussão, ela nos revelou acreditar que a prática e a teoria, quando trabalhadas juntas, favorecem o aprendizado dos alunos. Logo, constatamos que o alerta 1 foi o responsável por desencadear o alerta 2. Ainda durante a análise de suas falas, identificamos apenas um "momento" em que Gisa reestruturou suas estratégias de ação e pensou em como poderia proceder em uma ação futura, a partir do alerta 1. Portanto, esse foi o único momento em que ela realizou reflexões sobre a reflexão-na-ação.

Ao interpretarmos o esquema da prática reflexiva de Gisa, percebemos que ela se deparou com uma situação-problema durante o planejamento do microensino, a qual se refere ao momento de realização da atividade experimental, classificada como sendo o alerta 1. Logo, interpretamos que essa 
situação não se enquadrava dentro dos limites do que ela aprendeu a tratar como normal, o que a levou, por meio de um diálogo reflexivo, a pensar em uma resposta que não fosse de rotina. Por isso, em um momento de estruturação da sua prática de ensino, Gisa expõe o problema e explica que pretendia ter conduzido sua aula de modo a articular a prática e a teoria.

Ao assistirmos o seu microensino e a partir da análise das nossas discussões, constatamos como resultado inesperado o fato de Gisa não ter conseguido articular a teoria e a prática como planejado, e por isso conduziu a abordagem do conteúdo de forma apressada e superficial, para que o tempo fosse suficiente para realizar a atividade experimental. Então, Gisa questiona as suas reflexões com base nesse resultado e pensa em como poderia ter ocorrido a aula se a tivesse conduzido de outra forma, ou seja, se tivesse realizado a atividade experimental no início do microensino.

Em um momento de reestruturação da sua prática docente, Gisa pensa criticamente e conclui suas reflexões defendendo que o ideal seria ter trabalhado com a atividade experimental durante a aula. Interpretamos, portanto, que a sua dúvida em relação ao momento de realização do experimento e o fato de não ter conseguido conduzir a aula da forma como planejou levaram-na a questionar a sua estrutura de pressupostos do ato de conhecer-na-ação e as suas estratégias de ensino, pensando em uma forma de melhorar a sua prática de ensino para ações futuras (SCHÖN, 2000).

Por fim, em um momento em que Gisa planeja uma nova ação, reconhece que poderia ter conduzido a aula de forma diferente, reforçando suas reflexões sobre a reflexão para ação a respeito da realização da atividade experimental. Dessa forma, podemos supor que em uma próxima ação Gisa irá trabalhar de modo a articular a teoria e a prática, o que era sua intenção desde o planejamento do microensino, mas que acabou não acontecendo.

\section{Síntese das análises das reflexões dos estudantes participantes da pesquisa}

Ao analisarmos as práticas reflexivas de cada estudante, constatamos que as situações-problema identificadas em seus microensinos, que os levaram a ficar em estado de alerta, advém de fatores de natureza diversa. Além disso, cada um deles se deparou com uma dificuldade ao preparar e ao ministrar a aula, o que desencadeou outras situações-problema, que os estimularam a refletir para buscar soluções práticas do seu ensino. Constatamos também que nem todos refletiram sobre a reflexão-na-ação a respeito de todas as situações-problema que emergiram durante a sua aula. Isso significa que nem todos estruturaram, questionaram e reestruturaram a sua ação a partir de todos os alertas identificados.

Para isso, Schön (1992, 2000) explica que os "momentos" de questionamento e reestruturação do ato de conhecer-na-ação podem ser resumidos em um processo único, o que justifica o fato desses momentos não ter ocorrido com a mesma frequência nas práticas reflexivas de Liz, Zeca e Gisa, uma vez que os estudantes se depararam com dificuldades de natureza diversa, o que pode ser explicado por apresentarem distintas formas de conceber o processo de ensinar. 
Schön $(1992,2000)$ ainda nos esclarece que os momentos de reflexão-naação não são tão claros um em relação ao outro, uma vez que um elemento surpresa que emerge de determinada situação de ensino pode apresentar-se de forma a parecer já interpretado. Por isso, ao estudarmos o conteúdo das reflexões de cada estudante percebemos que Liz, Zeca e Gisa não refletiram de forma sequencial, assim como explica Schön a respeito da prática reflexiva. Verificamos que em alguns momentos da discussão eles retomavam um ponto já comentado ou repetiam algo que já havíamos discutido, movimento este, que consideramos ocorrer em torno de um "eixo imaginário" existente no interior de uma espiral, o qual representa a prática docente. Portanto, as reflexões acerca da prática docente sustentam a continuidade dos movimentos reflexivos e mantém a arquitetura da espiral.

A seguir, apresentamos na Figura 6, uma representação esquemática do percurso realizado para identificar, analisar e interpretar o conteúdo das reflexões de Liz, Zeca e Gisa.

Figura 6-Delineamento dos movimentos que caracterizam uma prática docente reflexiva

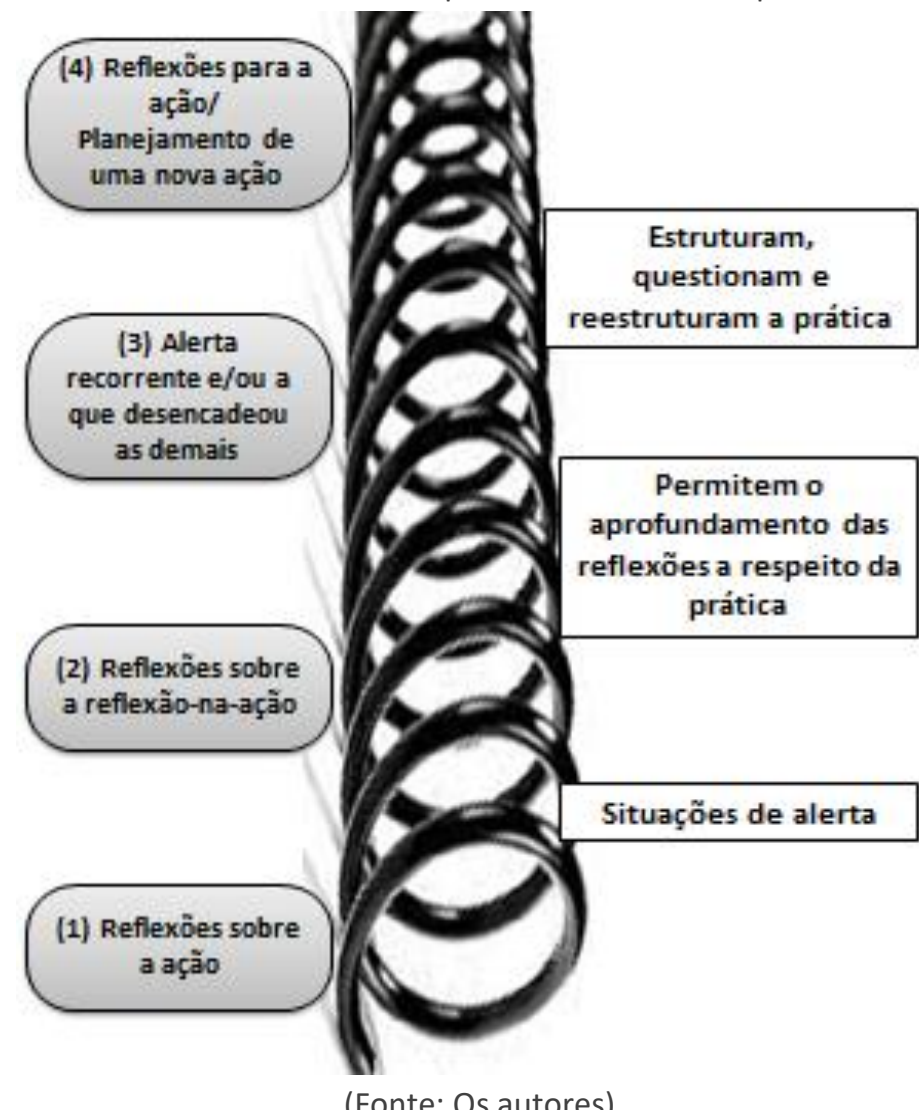

Vale ressaltar que todo esse delineamento só é possível de ser realizado se tomarmos como ponto de partida as reflexões sobre a ação, motivo pelo qual o esquema apresentado pela Figura 6 consiste em uma espiral que não apresenta começo e fim, ou seja, as reflexões são contínuas e vão ocorrendo à medida que o sujeito sente a necessidade de reestruturar a sua prática de ensino a partir do surgimento de um elemento surpresa (alerta) que não se enquadra no seu sistema de referências, ou seja, que o faz refletir a respeito das suas percepções sobre o processo de ensino. 
A estratégia da autoscopia já foi implementada em outras investigações, porém, em diferentes contextos e perpassando pelas fases pré-ativa, interativa e pós-ativa, caracterizando a Autoscopia Trifásica. Podemos citar o estudo realizado por Rosa-Silva (2008), no qual a autora propôs o desenvolvimento de uma Autoscopia Trifásica na formação continuada de uma professora de Ciências, constatando que o procedimento disciplina o professor a planejar as aulas, refletindo para a ação; favorece a reflexão sobre a ação passada, confrontando o plano de aula e as ações que ocorreram em sala; e desenvolve a reflexão na ação, levando o profissional a ficar alerta diante de determinadas situações em aula, para, imediatamente, tomar atitudes. Como já mencionado anteriormente este estudo nos inspirou a propor a Autoscopia Bifásica (ROSA-SILVA; LORENCINI JR.; LABURÚ, 2010).

Na investigação realizada por Vacheski (2016), a Autoscopia Trifásica foi desenvolvida na formação inicial de licenciandos em Química durante o estágio de regência na escola, o que possibilitou a identificação, na fase pré-ativa, das concepções dos licenciandos sobre o professor nos processos de ensino e de aprendizagem; organização da Sequência Didática; relação entre o enfoque CTS e as estratégias de ensino; o aluno crítico e o juízo de valor; concepções sobre a abordagem CTS; conhecimento prévio x conhecimento científico; e avaliação. Já na fase pós-ativa, foram identificados os momentos reflexivos dos estudantes que indicaram possíveis mudanças da prática educativa em ações futuras.

Do mesmo modo, nosso estudo está alinhado a essa perspectiva, embora não tenhamos acompanhado o planejamento das atividades dos estudantes, "descartando" a etapa pré-ativa e já partindo para as fases interativa e pós-ativa, caracterizando uma Autoscopia Bifásica. Consideramos que os princípios da epistemologia de Schön, no que se refere ao sujeito reflexivo, estão presentes e podem ser identificados na fase pós-ativa, o que nos leva a inferir que a fase pósativa se mostrou regularmente reflexiva, com processos reflexivos da tipologia schoniana. Durante essa fase, estimulamos os estudantes a realizarem reflexões sobre a ação, as quais possibilitaram que interviéssemos novamente, estimulando-os a realizar reflexões sobre a reflexão-na-ação.

\section{CONSIDERAÇÕES FINAIS}

Ao longo desta investigação buscávamos uma resposta para a seguinte questão: "De que forma as reflexões dos estudantes de um curso de Licenciatura em Química podem interferir no desenvolvimento do processo de aprender a ensinar?", para respondê-la foi necessário identificar as reflexões dos estudantes e em seguida analisar e interpretar o conteúdo dessas reflexões e o que elas indicavam a respeito das suas percepções sobre o processo de ensino.

A Autoscopia Bifásica possibilitou a filmagem dos microensinos dos estudantes na fase interativa e a identificação das situações-problema decorrentes das suas práticas de ensino na fase pós-ativa. Ainda nesta segunda fase, por meio de uma intervenção reflexiva realizada com Liz, Zeca e Gisa foi possível ajudá-los a refletir e buscar soluções para tais situações. Assim, foi possível constatarmos que as situações identificadas advêm de fatores de natureza diferente, que os levaram a se posicionar em estado de alerta e a realizarem reflexões sobre a reflexão-na-ação, as quais possibilitaram que eles 
revelassem as suas formas de perceber e refletir o ensino a partir das situações vivenciadas durante o microensino.

No entanto, percebemos ao longo da análise que nem todos os estudantes refletiram sobre a reflexão-na-ação a respeito de todas as situações-problema que emergiram durante a sua aula. Isso significa que nem todos estruturaram, questionaram e reestruturaram a sua ação a partir de todos os alertas identificados. Para esse fato Schön $(1992,2000)$ explica que os momentos de reflexão-na-ação não são tão claros um em relação ao outro, uma vez que um elemento surpresa que emerge de determinada situação de ensino pode apresentar-se de forma a parecer já interpretado. Logo, podemos inferir que Liz, Zeca e Gisa não refletiram de forma sequencial e por isso, para analisar o conteúdo de suas reflexões foi necessário selecionar, organizar e alterar a ordem das falas.

Tal alteração não prejudicou os resultados da análise, pois, verificamos que apesar dos estudantes terem se deparado com mais de uma situação-problema ao longo do microensino, foi possível constatar que uma delas sempre era a responsável por desencadear as demais. Desse modo, foi possível apresentarmos de forma clara os momentos que compõem o esquema da prática reflexiva de cada um, evidenciando as reflexões realizadas em cada um desses momentos, com vistas à transformação da sua prática e do próprio estudante. Por fim, foi possível ainda sistematizar o modelo de análise em espiral, já que os momentos reflexivos não ocorreram de forma sequencial e ainda apresentaram avanços e retrocessos em vista da necessidade de aprofundamento das reflexões para encontrar soluções práticas de ensino.

Além disso, podemos inferir que as reflexões para a ação foram regularmente evidenciadas na fase pós-ativa, pois identificamos, nas falas dos estudantes, reflexões sobre o seu planejamento, as quais classificamos como reflexões sobre a reflexão para ação. Por meio dessas reflexões, observamos que Liz, Zeca e Gisa planificaram as ações futuras na fase pós-ativa, embora não tiveram auxilio da pesquisadora na fase pré-ativa. O desenvolvimento profissional dos estudantes tem por finalidade a aprendizagem e o desenvolvimento dos alunos (ALARCÃO, 1996). Assim sendo, os sujeitos envolvidos se encontram em constante desenvolvimento provocado pelas relações didáticas entre os vários setores que envolvem o processo educativo.

Tendo como ponto de partida as reflexões sobre a ação, podemos inferir que os formadores de professores podem intervir estimulando os estudantes a refletirem sobre a reflexão-na-ação e, assim, a reconhecerem e a aprenderem a lidar com os problemas decorrentes da sua prática de ensino, o que ocorre a partir da descrição do seu ato de conhecer-na-ação, que, por sua vez, leva-os a elaboração de novas estratégias de ação (SCHÖN, 1992; 2000). 


\title{
Analysis of the reflections of graduates in chemistry in teaching situations
}

\begin{abstract}
The objective of this research was to identify and analyze of the reflections of students of the graduation course in Chemistry, as well as to the implications of these reflections for the development of the process of learning to teach. The data collection was performed through Biphasic Autoscopy integrated to the micro-teaching, a procedure that allowed the videotaping of the micro-teaching in the interactive phase and, through an interview, the identification of the problem situations arising from the practices of each one in the post-active phase. We identified that, although the students have faced problem situations in running their teaching activity, one of them was always responsible for unleashing all the others. Thus, we sought to catalog moments in which they reflected on such a situation aiming to transform their practice. So that, it was possible to identify moments of students' reflective practice and to verify that they did not occur in a sequential manner, but rather characterized by advances and setbacks, which allowed us to elaborate a spiral model that illustrates reflexive movements in a practice situation education.
\end{abstract}

KEYWORDS: Teaching practice. Reflective initial formation. Chemistry. Autoscopy. 


\section{REFERÊNCIAS}

ALARCÃO, I. Professores reflexivos em uma escola reflexiva. 2 ed. São Paulo: Cortez, 2003.

ALARCÃO, I. Reflexão crítica sobre o pensamento de D. Schön e os programas de formação de professores. In: ALARCÃO, I. (Org.). Formação Reflexiva de Professores: estratégias de Supervisão. Porto: Porto Editora, 1996, p. 9-40. (Coleção CIDInE)

ARRIGO, V. Estudo sobre as reflexões dos estudantes em Química nas atividades de microensino: implicações para a formação inicial docente. 2015. $122 \mathrm{f}$. (Dissertação de mestrado) Universidade Estadual de Londrina, Londrina, 2015.

ARRIGO, V.; LORENCINI JR., Á.; BROIETTI, F. C. D. A autoscopia bifásica integrada ao microensino: uma estratégia de intervenção reflexiva na formação de professores de química. Investigações em Ensino de Ciências, v. 22, n. 1, p. 1-22, 2017.

BOGDAN, R. C.; BIKLEN, S. K. Investigação qualitativa em educação. Porto: Porto Editora, 1994.

BARSIL. Resolução CNE/CP 2/2015, de 01 de julho de 2015. Define as Diretrizes Curriculares Nacionais para a formação inicial em nível superior (cursos de licenciatura, cursos de formação pedagógica para graduados e cursos de segunda licenciatura) e para a formação continuada. Diário Oficial da União, Brasília, 2 jul. 2015.

BROIETTI, F. C. D.; STANZANI, E. L. Os estágios e a formação inicial de professores: experiências e reflexões no curso de Licenciatura em Química da UEL. Química Nova na Escola, v. 38, n. 3, p. 306-317, 2016.

CARVALHO, A. M. P. de; GIL-PÉREZ, D. Formação de professores de Ciências: tendências e inovações. 7 ed. São Paulo: Cortez, 2003.

CLARKE, A. Student-teacher reflection: developing and defining a practice that is uniquely one's own. International Journal Science Education, v. 16, n. 5, p. 497509, 1994.D

DEWEY, J. Como pensamos: como se relaciona o pensamento reflexivo com o processo educativo, uma reexposição. 4. ed. São Paulo: Nacional, 1979. 
FERNANDES, S. D. S. Vídeo-formação: uma experiência de videoscopia com professores estagiários. 2004. 140f. (Dissertação de mestrado), Universidade do Minho, Braga, 2004.

GATTI, B. A. A formação inicial de professores para a educação básica: as licenciaturas. Revista USP, n. 100, p. 33-46, 2014.

GATTI, B. Formação de professores no Brasil: características e problemas. Educação \& Sociedade, v. 31, n. 113, p. 1355-1379, 2010.

GAUCHE, R.; SILVA, R. R.; BAPTISTA, J. A.; SANTOS, W. L. P.; MÓL, G. S.; MACHADO, P. F. L. Formação de Professores de Química: concepções e proposições. Química Nova na Escola, n. 27, 2008, p. 26-29.

INSTITUTO NACIONAL DE ESTUDOS E PESQUISAS EDUCACIONAIS ANÍSIO TEIXEIRA. Sinopse Estatística da Educação Superior 2016. Brasília: Inep, 2017. Disponível em: <http://portal.inep.gov.br/web/guest/sinopses-estatisticas-daeducacao-superior>. Acesso em: 06 mar. 2018.

LORENCINI JR., Á. As demandas formativas do professor de ciências. In: CAINELLI, M. R.; SILVA, I. F. (Org.). $O$ estágio na licenciatura: a formação de professores e a experiência interdisciplinar na Universidade Estadual de Londrina. Londrina: UEL, 2009. p. 21-41.

LORENCINI JR., Á. O professor e as perguntas na construção do discurso em sala de aula. 2000. 243f. (Tese de doutorado), Universidade de São Paulo, São Paulo, 2000.

MALDANER, O. A. A formação inicial e continuada de professores de química: professores/pesquisadores. 4 ed. Ijuí: Unijuí, 2013.

NÓVOA, A. Formação de professores e profissão docente. In: NÓVOA, A. (Coord.). Os professores e a sua formação. Lisboa: Dom Quixote, 1992. p. 13-33.

PIMENTA, S. G. Professor reflexivo: construindo uma crítica. In: PIMENTA, S. G.; GHEDIN, E. (Orgs.). Professor reflexivo no Brasil: gênese e crítica de um conceito. 4 ed. São Paulo: Cortez, 2006. p. 17-52.

ROSA-SILVA, P. O. Estudo das reflexões sobre a ação de uma professora de Ciências: um caso de formação continuada. 2008. 188f. (Dissertação de mestrado), Universidade Estadual de Londrina, Londrina, 2008. 
ROSA-SILVA, P. O.; LORENCINI JR, Á.; LABURÚ, C. E. Análise das reflexões da professora de Ciências sobre a sua relação com os alunos e implicações para a prática educativa. Revista Ensaio, v. 12, n. 1, p. 63-82, 2010.

SAINT-ONGE, M. 0 ensino na escola: o que é, como se faz. 2 ed. São Paulo: Loyola, 2001.

SANT'ANNA, F. M. Microensino e habilidades técnicas do professor. São Paulo: McGraw-Hill do Brasil, 1979.

SCHÖN, D. A. Educando o profissional reflexivo: um novo design para o ensino e a aprendizagem. Tradução de Roberto Cataldo Costa. Porto Alegre: Artmed, 2000.

SCHÖN, D. A. Formar professores como profissionais reflexivos. In: NÓVOA, A. (Coord.). Os professores e a sua formação. Lisboa: Dom Quixote, 1992. p. 79-91.

SILVA, C. S.; OLIVEIRA, L. A. A. Formação inicial de professores de química: formação específica e pedagógica. In: NARDI, R. (Org.). Ensino de ciências e matemática I: temas sobre a formação de professores. São Paulo: Editora Unesp/Cultura Acadêmica, 2009.

SILVA, R. M. G.; SCHNETZLER, R. P. Concepções e ações de formadores de professores de Química sobre o estágio supervisionado: propostas brasileiras e portuguesas. Química Nova, v. 31, n. 8, p. 2174-2183, 2008.

SILVA, R. M. G.; SCHNETZLER, R. P. Estágios curriculares supervisionados de ensino: partilhando experiências formativas. EntreVer, v. 1, n. 1, p. 116-136, 2011.

TARDIF, M. Saberes Docentes e Formação Profissional. 11. ed. Petrópolis: Vozes, 2010. 325p.

VACHESKI, G. M. O. Atividades sob a perspectiva CTS na formação inicial de professores de Química: implicações para o desenvolvimento profissional docente. 2016. 203f. (Dissertação de mestrado), Universidade Estadual de Londrina, Londrina, 2016.

ZEICHNER, K. M. A Formação Reflexiva de Professores: Ideias e Práticas. Lisboa: Educa, 1993. 
ZUCCO, C.; PESSINI, F. B. T.; ANDRADE, J. B. Diretrizes curriculares para os cursos de Química. Química Nova, v. 22, n. 3, p. 454-461, 1999.

Recebido: 2017-06-19

Aprovado: 2018-03-28

DOI: $10.3895 /$ rbect.v11n3.6030

Como citar: ARRIGO, V.; LORENCINI JÚNIOR, Á.; BROIETTI, F. C. D. Análise das reflexões de licenciandos em química em situações de ensino. Revista Brasileira de Ensino de Ciência e Tecnologia, v. 11, n. 3, 2018. Disponível em:

<https://periodicos.utfpr.edu.br/rbect/article/view/6030>. Acesso em: xxx.

Correspondência: Viviane Arrigo - viviane_arrigo@hotmail.com

Direito autoral: Este artigo está licenciado sob os termos da Licença Creative Commons-Atribuição 4.0 Internacional.

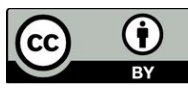

